\title{
Multi-drug resistant Escherichia coli in diarrhoeagenic foals: Pulsotyping, phylotyping, serotyping, antibiotic resistance and virulence profiling
}

\author{
C.A. Kennedy \\ University College Dublin \\ Ciara Walsh \\ Technological University Dublin, ciara.walsh@tudublin.ie \\ M. Karczmarczyk \\ University College Dublin, Ireland
}

See next page for additional authors

Follow this and additional works at: https://arrow.tudublin.ie/schfsehart

Part of the Food Science Commons, and the Veterinary Medicine Commons

\section{Recommended Citation 30173740 . \\ This Article is brought to you for free and open access by the School of Food Science and Environmental Health at ARROW@TU Dublin. It has been accepted for inclusion in Articles by an authorized administrator of ARROW@TU Dublin. For more information, please contact arrow.admin@tudublin.ie, aisling.coyne@tudublin.ie, gerard.connolly@tudublin.ie.}

Kennedy CA, Walsh C, Karczmarczyk M, O'Brien S, Akasheh N, Quirke M, Farrell-Ward S, Buckley T, Fogherty U, Kavanagh K, Parker CT, Sweeney T, Fanning S. Multi-drug resistant Escherichia coli in diarrhoeagenic foals: Pulsotyping, phylotyping, serotyping, antibiotic resistance and virulence profiling. Vet Microbiol. 2018 Sep;223:144-152. doi: 10.1016/j.vetmic.2018.08.009. Epub 2018 Aug 7. PMID:

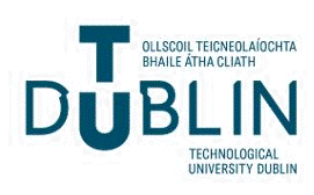




\section{Authors}

C.A. Kennedy, Ciara Walsh, M. Karczmarczyk, S. O'Brien, N. Akasheh, M. Quirke, S. Farrell-Ward, T. Buckley, U. Fogherty, K. Kavanagh, C.T. Parker, T. Sweeney, and S. Fanning 
VETMIC-2018-404 (revised, version 1)-

3

Multi-drug resistant Escherichia coli in diarrhoeagenic foals: pulsotyping,

phylotyping, serotyping, antibiotic resistance and virulence profiling.

8 C.A. Kennedy ${ }^{a}$, C. Walsh ${ }^{b, c}$, M. Karczmarczyk ${ }^{c}$, S. O’Brienc,N. Akasheh ${ }^{d}$, M. Quirke ${ }^{\text {, }}$,

9 S. Farrell-Wardc, T. Buckleye, U. Foghertye, K. Kavanaghe, C.T. Parker ${ }^{f}$, T. Sweeneya and S. Fanning ${ }^{\mathrm{c}}$.

aUCD Veterinary Sciences Centre, University College Dublin, Belfield, Dublin 4,

Ireland, bSchool of Food Sc. and Environmental Health, Cathal Brugha Street, DIT,

Dublin D01 HV58, Ireland, 'UCD-Centre for Food Safety, School of Public Health,

Physiotherapy \& Population Science, University College Dublin, Belfield, Dublin D04

N2E5, Ireland, 'Medical Directorate, St. James's Hospital, Dublin 8, Ireland, eIrish

18 Equine Centre, Johnstown, Naas, Co. Kildare, W91 RH93, Ireland and fProduce

19 Safety and Microbiology Research Unit, Agricultural Research Service, U.S.

Department of Agriculture, 800 Buchanan Street, Albany, CA 94710, USA.

Corresponding author:

Professor Séamus Fanning, UCD-Centre for Food Safety, School of Public Health, Physiotherapy \& Sports Science, University College Dublin, Belfield, Dublin D04 N2E5, Ireland.

Tel.: (+353) 17162869

sfanning@ucd.ie 


\section{Abstract}

32 Extraintestinal pathogenic E. coli (ExPEC) possess the ability to cause extraintestinal infections such as urinary tract infections, neonatal meningitis and sepsis. While

34 information is readily available describing pathogenic $E$. coli populations in foodproducing animals, studies in companion/sports animals such as horses are limited.

36 In addition, many antimicrobial agents used in the treatment of equine infections are

37 also utilised in human medicine, potentially contributing to the spread of antibiotic resistance determinants among pathogenic strains. The aim of this study was to phenotypically and genotypically characterise the multidrug resistance and virulence associated with 83 equine $E$. coli isolates recovered from foals with diarrhoeal disease. Serotyping was performed by both PCR and sequencing. Antibiotic resistance was assessed by disc diffusion. Phylogenetic groups, virulence genes, antibiotic resistance genes and integrons were determined by PCR. Thirty-nine $(46 \%)$ of the isolates were classified as ExPEC and hence considered to be potentially pathogenic to humans and animals. Identified serogroups $\mathrm{O} 1, \mathrm{O} 19 \mathrm{a}, \mathrm{O} 40$, O101 and $\mathrm{O} 153$ are among previously reported human clinical ExPEC isolates. Over a quarter of the E. coli were assigned to pathogenic phylogroups B2 (6\%) and D (23\%). Class 1 and class 2 integrons were detected in $85 \%$ of E. coli, revealing their potential to transfer MDR to other pathogenic and non-pathogenic bacteria. With $65 \%$ of potentially pathogenic isolates harbouring one or more TEM, SHV and CTXM-2 group $\beta$-lactamases, in addition to the high levels of resistance to fluoroquinolones observed, our findings signal the need for increased attention to companion/sport animal reservoirs as public health threats. 
Keywords: Escherichia coli, diarrhoeagenic foals, serotyping, antibiotic resistance, adherence and invasion PFGE, ExPEC, ESBL

Introduction

Pathogenic Escherichia coli infection is a public health challenge and a continuous source of morbidity/mortality (Croxen et al., 2013). Pathogenic E. coli can be split into two categories: intestinal and extraintestinal pathogenic E. coli. Intestinal pathogenic E. coli cause diarrhoea by expressing virulence genes that produce enterotoxins, facilitate attachment and effacement, and/or invasion of the intestinal mucosa. Extraintestinal pathogenic E. coli (ExPEC) possess the ability to cause extraintestinal infections such as urinary tract infections (UTIs), neonatal meningitis and sepsis (Russo and Johnson, 2003). Sources of human infection include direct or indirect contact with animals that carry pathogenic E. coli, and from exposure to animal faeces. Recent outbreaks in public settings, such as farms, fairs and petting zoos, have highlighted the public health impact of this route of transmission (Byrne et al., 2015; Murray et al., 2017). While information is readily available describing pathogenic E. coli populations in food-producing animals (Lenahan et al., 2007; Lenahan et al., 2009; Kennedy et al., 2017), studies in companion/sports animals such as horses are limited.

One such study, focusing on E. coli distribution, reported a greater diversity among pathogenic E. coli populations in horses relative to cattle or humans (Anderson et al. 2006). In addition, many of the antimicrobial agents used in the treatment of equine

77 infections belong to the same families as used in human medicine (WHO, 2017). 
pathogenic strains; as the in vitro and in vivo transmission of resistance markers between species has been described previously (Kelly et al., 2009).

Given the high degree of handling and the large number of people (particularly children) who have contact with horses, there is a need to increase awareness of companion/sports animals as potential reservoirs of multi-drug resistant (MDR) and pathogenic E. coli (Sequeria et al., 2009; Murray et al., 2017). The aim of this study was to characterise multidrug resistance determinants and virulence genes and to phenotypically characterise those associated with equine $E$. coli isolates recovered from foals with diarrhoeal disease.

88

\section{Materials and methods}

Bacterial isolate collection and antimicrobial resistance profiling

Faecal samples routinely obtained from foals with enteritis and from post mortem examinations presenting at the Irish Equine Centre in Kildare, Ireland were cultured onto Columbia blood Agar, Wilkins Chalgren agar (anaerobically) and MacConkey agar and incubated overnight at $37^{\circ} \mathrm{C}$. Presumptive $E$. coli were confirmed using API 20E strips (bioMériux, Marcy l'Etoile, France) and antibiotic resistance profiles of all isolates were determined against a panel of 14 compounds using disc diffusion, and where appropriate interpreted according to Clinical and Laboratory Standards Institute (CLSI) guidelines (CLSI document VET01-A4, 2013; CLSI supplement VET01S, 2015). Resistance to antimicrobial agents not listed in the CLSI guidelines was determined by the absence of a zone of clearance. The following antimicrobial compounds were included, with their abbreviations and concentrations in parenthesis; ampicillin $(A, 10 \mu \mathrm{g})$; amikacin $\left(A_{K}, 30 \mu \mathrm{g}\right)$; amoxillin/clavulanic acid ( $A_{M}$, 20/10 $\mu \mathrm{g})$; gentamicin ( $\left.\mathrm{C}_{\mathrm{N}}, 10 \mu \mathrm{g}\right)$; ciprofloxacin (CP, $\left.5 \mu \mathrm{g}\right)$; enrofloxacin (E, $\left.5 \mu \mathrm{g}\right)$, 
104 kanamycin $(\mathrm{K}, 30 \mu \mathrm{g})$, cephalothin $\left(\mathrm{K}_{\mathrm{F}}, 30 \mu \mathrm{g}\right)$, nalidixic acid $\left(\mathrm{N}_{\mathrm{A}}, 30 \mu \mathrm{g}\right)$; norfloxacin

105 (No, $10 \mu \mathrm{g})$; streptomycin (S, $10 \mu \mathrm{g})$; sulfonamide $\left(\mathrm{S}_{3}, 300 \mu \mathrm{g}\right)$; tetracycline (T, 30

$106 \mu \mathrm{g})$ and trimethoprim $(\mathrm{W}, 5 \mu \mathrm{g})$. All antimicrobial-containing discs were supplied by

107 Oxoid (Fannin Healthcare, Dublin, Ireland). Quality control strains, E. coli

108 ATCC ${ }^{\circledR} 25922$ and Pseudomonas aeruginosa ATCC ${ }^{\circledR} 27853$, were included. Eighty-

109 three isolates were identified that were resistant to 3 or more different antimicrobial

110 classes. These were defined as MDR and were subsequently characterised in

111 greater detail, as described below.

112

113 DNA purification

114 Total DNA was prepared from all isolates using the Promega Wizard Genomic DNA

115 purification kit (Madison, WI) following the manufacturer's instructions. The integrity and

116 concentration of the purified template DNA was assessed by means of conventional agarose

117 gel $[1.5 \%,(\mathrm{w} / \mathrm{v})]$ electrophoresis and by spectrophotometry using a NanoDrop ${ }^{\mathrm{TM}}$ ND-1000

118 (Thermoscientific, Wilmington, DE).

120 Serotyping

121 Molecular serotyping was performed on all E. coli isolates using PCR amplification of

122 the serogroup specific genes, rfbo26, $r f b o 111$ and $r f b o 157$.

123 A representative group of 25 isolates were then selected at random and sent for

124 conventional serotyping (Public Health England, PHE Colindale, London, UK).

126 Pulsed-field gel electrophoresis (PFGE)

127 Molecular subtyping using pulsed-field gel electrophoresis (PFGE) of genomic DNA

128 recovered from equine $E$. coli isolates was performed according to methods described previously (Duffy et al., 2005). Similarity clustering analyses were 
130 performed using an unweighted pair group-matching algorithm and the Dice

131 correlation coefficient with a tolerance and optimization of $1.5 \%$ with BioNumerics

132 (Applied Maths, Belgium).

\section{Phylogenetic grouping}

135 Phylogenetic groups were determined for each $E$. coli isolate using an established multiplex PCR targeting chuA, yjaA, and TSPE4.7 according to the protocol of

137 Clermont et al. (2000). Target amplification was performed using the original primer

138 concentrations (Table 1) and cycling conditions (Supplemental Material Table S1).

139 Amplicons generated were separated by conventional 1.7\% (w/v) agarose gel

140 electrophoresis, stained with $0.1 \mathrm{~g} / \mathrm{ml}$ ethidium bromide (Sigma-Aldrich) in 0.5X Tris-

141 EDTA-boric acid buffer, and subsequently assigned to one of the phylogroups A, B1,

142 B2, or D using the criteria outlined previously by Clermont et al. (2000).

\section{Adherence and invasion assay}

145 Six representative isolates (denoted as Eq23, Eq45, Eq59, Eq67, Eq69 and Eq79) with 146 distinctly different virulence profiles (Supplemental Material Table S2) were selected. These

147 were assessed for their ability to adhere and invade Caco-2 cells as a model for the human

148 small intestinal epithelium. A bacterial adhesion assay was performed with a multiplicity of

149 infection (MOI) of 100 bacteria per epithelial cell according to previously described methods

150 (Simpson et al., 2006). For the invasion assay, Caco-2 monolayers were infected with the

151 same $\mathrm{MOI}$ and incubated for $30 \mathrm{~min}$ at $37^{\circ} \mathrm{C}$ to allow invasion to occur. The number of

152 intracellular bacteria was determined after the extracellular bacteria were eliminated by

153 incubation of the monolayers with the experimental medium containing gentamicin (100 $\mu \mathrm{g} / \mathrm{mL}$ ) for a further $30 \mathrm{~min}$ at $37^{\circ} \mathrm{C}$. 
155 All monolayers were subsequently lysed with a $0.5 \mathrm{~mL}$ volume of PBS containing $1 \%$

$156(\mathrm{v} / \mathrm{v})$ Triton X-100. Bacteria from each monolayer were collected and plated onto

157 tryptone soy agar (TSA, Sigma) using decimal dilutions. Plate counts from the

158 adhesion assay determined the total number of associated (adhered and invaded)

159 bacteria, and plate counts from the invasion assay determined the number of

160 invaded bacterial cells only. Adherent non-invasive (+-), invasive $(++)$ and non-

161 adherent and non-invasive (--) controls were included in each experiment.

162

163 Identification of antimicrobial resistance determinants, integrons, gene

164 cassettes and virulence genes

165 Detection of antibiotic resistance markers and integron-associated genes was performed by PCR, using the primers listed in Table 1. The following resistance determinants were investigated: ampC, blactх-м-2, blaoxA, blashv, blatem, blapse, encoding $\beta$-lactamases and $\beta$-lactamase groups; tet( $A)$ and $\operatorname{tet}(\mathrm{G})$ tetracycline efflux

169 pumps; and the sulfonamide resistance gene sul1.

170 A PCR amplification of the gyrA gene was performed on a subset of 16 ciprofloxacin 171 resistant isolates. Previously published PCR methods were employed to determine

172 the presence of conserved integron-associated genes in all isolates, including int/1

173 and intl2 (coding for integrases of classes 1 and 2, respectively), qacE $\Delta 1$, sul1, the

174 right-sided conserved segments of class 1 integrons, together with their variable

175 regions (Table 1). Gene cassettes and specific gyrA amplicons of interest were gel 176 extracted using a Qiagen gel extraction kit (West Sussex, UK). DNA was quantified

177 by spectrophotometry and sequenced commercially (Qiagen, Hilden, Germany).

178 Sequence similarity searches were carried out against sequences deposited in the

179 GenBank database using the BLAST search tool 
180 (https://blast.ncbi.nlm.nih.gov/Blast.cgi). Sequence alignments were performed using

181 the online CLUSTALW2 program available at the European Bioinformatics Institute

182 (https://www.ebi.ac.uk/Tools/msa/clustalw2/).

183 All isolates were investigated for the presence of the following virulence-associated

184 genes: stx1 and stx2 which encode Shiga-toxins; eaeA, an adherence factor; the 185 alpha-haemolysin, hlyA; fliCh7, encoding the flagellar antigen $\mathrm{H} 7$; cnf1, a cytotoxic necrotizing factor from uropathogenic E. coli; iucD, which encodes the aerobactin operon; afa/draBC, a Dr-binding adhesin (F17 fimbriae); papC, a P fimbriae; sfa/focDE, the S and F1C fimbriae; and neuC, a K1 gene implicated in sialic acid synthesis (Table 1$)$.

PCR amplification reaction conditions for all of the investigated genes are presented in supplemental material (Supplemental Material Table S1). All reactions contained $100 \mathrm{ng}$ of purified DNA, $50 \mathrm{pmol} / \mu \mathrm{L}$ of forward and reverse primers (MWG-Biotech

194 AG, Ebersberg, Germany), 10 X amplification buffer containing $2.5 \mathrm{mM} \mathrm{MgCl}, 200$ $\mu \mathrm{M}$ dNTPs (Promega, Madison, WI) and 0.5 U TaqDNA Polymerase (New England Biolabs, Ipswich, MA) or Pfu Polymerase (Chimerx, Madison, WI).

\section{Results and Discussion}

\section{Serotyping}

200 Initially, PCR was carried out on all 83 equine $E$. coli isolates in order to assign them

201 to one of three known pathogenic E. coli serogroups ( $r f b 0157, r f b o 26$ and $r f b 0111)$. One 202 isolate in this study produced a PCR product for serogroup O26, while no amplicons 203 corresponding to the serogroups 0157 or 0111 were detected (Table 2). However, 204 of the 25 representative isolates sent for conventional serotyping, 10 were typeable 
(E. coli O1, O101, O153, O19a, O33, O40, O91; Table 2). All but the O19a serogroup have previously been reported in animal sources including: foals, cattle,

207 pigs, sheep, goats, poultry, cats (Krause et al., 2005; Mora et al., 2011). Serogroups

208 O1, O26, and 0101 have previously been associated with both healthy and

209 diarrhoeagenic foals (Holland et al., 1996) however, this is the first reported

210 collection of $E$. coli isolates from equine sources to contain serogroups O19a, O33,

211 O40, O91 and 0153, though they have been previously assessed for biocide

212 tolerance in a separate study (Sheridan et al., 2012). In human infection, all 8

213 serogroups are of clinical significance. All but O19a have previously been associated

214 with human clinical shiga toxin-producing E. coli (STEC) infection (Werberet. al.,

215 2008; Vally et al., 2012) and serogroups O1, O19a, O40, O101 and O153 have also

216 been identified among human clinical ExPEC isolates (Ciesielczuk et al., 2016).

217 Novel STEC/ETEC hybrid strains have been recently associated with patients with

218 haemolytic uraemic syndrome (HUS), these included isolates of the serogroups

219 O101 and 0153 (Nyholm et al., 2015). The German outbreak involving E. coli

220 reported in 2011 was linked to a hybrid STEC/EAEC, a feature which highlighted the danger of these combinations and the need to routinely screen for multiple sets of virulence factors (Mora et al., 2011).

Virulence gene characterisation

226 Of the 83 equine E. coli isolates examined, none were found to harbour the stx 1 or stx 2 genes; the absence of a single STEC isolate in this collection is unexpected considering the recent increase in outbreaks associated with 
229 domesticated/companion animals in public settings (Byrne et al., 2015, Murray et al.,

230 2017).

231 Of the 11 virulence genes investigated (Table 1), only 4 were detected among these

232 equine $E$. coli isolates (Table 3). Isolates harbouring two or more of these virulence

233 genes are defined as extraintestinal pathogenic E. coli (ExPEC) (Xia et al., 2011).

234 Thirty-nine (46\%) of the isolates in this study were classified as ExPEC on this basis, 235 and hence are considered to be potentially pathogenic to humans and animals. The

236 most commonly detected virulence gene in the collection was iucD (57\%). This gene

237 codes for a siderophore (an iron chelating compound), which enables E. coli to

238 survive in iron-poor environments such as those encountered in UTIs and is related

239 to the virulence of septicemic E. coli from non-equine sources (Siqueria et al., 2009).

240 The occurrence of the fimbrae $F 17$ gene afa/draBC (31\%) is comparable to the

241 results of one of few studies available on E. coli in horses (van Duijkeren et al.,

242 2000). Van Duijkeren and colleagues identified the presence of afa/draBC in $30 \%$ of

243 E. coli recovered from horses with diarrhoeal disease, and none in E. coli from

244 healthy horses, suggesting that these fimbrae might have a role in the cause of

245 diarrhoeal disease in horses. $F 17$ has also been associated with mastitis

246 (Ghanbarpour and Oswald, 2010). The papC gene, producing an adhesin associated

247 with both extraintestinal pathogenicity and an increased capacity to colonize the

248 human intestine, was identified in $36 \%$ of isolates. In animals, the papC gene has

249 also been associated with UTIs, respiratory tract infections, soft tissue infections and

250 diarrhoeagenic infection (Siqueria et al., 2009; Ewers et al., 2014). The presence of

251 the sfa/focDE gene was determined in only $2 \%$ of isolates. It has been associated

252 with biofilm production in E. coli (Naves et al., 2008); biofilm forming properties are

253 considered important for bacteraemia in the urinary tract of humans and animals 
254 (Wiles et al., 2008). All four virulence determinants are frequently documented in

255 EXPEC E. coli populations and are of clinical significance (Wiles et al., 2008). In

256 addition, we extended the genetic analysis of ten ExPEC isolates by means of a $E$.

257 coli K12 O157 v2 DNA microarray (Kyle et al. 2010) confirming the presence of

258 these virulence genes and revealing further putative virulence, stress, quorum

259 sensing and antimicrobial resistance (including efflux and porins) genes of interest

260 (Supplemental Material; Word document 1 and Figure S1). These results signal the need for increased attention to be focused on companion/sport animal reservoirs as

262 potential public health risks.

PFGE subtyping and phylogenetic classification

The collection of equine $E$. coli had a diverse range of pulsotypes of which 33 could be grouped into 9 clusters $(\mathrm{C} 1-9)$ of 3 or more isolates based on a genetic relatedness criterion of $80 \%$ (Figure 1). Six pulsotypes (A, B, C, D, E and J) were common to 2 isolates; 4 pulsotypes $(F, G, H, I)$ were common to 3 isolates; 60 isolates had distinct pulsotypes. Pulsotypes $A$ and $B$ were closely related with percentage similarity at $93 \%$ confidence and all 4 isolates belonged to the same phylogenetic group A.

273 According to Clermont et al. (2000), E. coli belonging to phylogenetic groups $\mathrm{A}$ and

274 B1 are considered non-pathogenic commensal strains, while strains belonging to 275 groups B2 and D are more likely to be pathogenic. The majority of isolates belonged 276 to phylogenetic group A (57\%); while the remainder of isolates belonged to

277 phylogenetic groups B1 (14\%), B2 (6 \%) and D (23\%). 
279 ExPEC belonging to both pathogenic and non-pathogenic phylogenetic groups were

280 isolated from foals presenting with diarrhoea. This result is in contrast with other

281 studies reporting on equine and other $E$. coli populations wherein ExPEC isolates

282 predominantly belong to phylogroup B2 (Xia et al., 2011; Ewers et al., 2014).

283 Although typing of human isolates shows good correlation between the phylogenetic

284 group and pathogenicity (Clermont et al., 2000), animal-associated ExPEC can be

285 phylogenetically distinct. Therefore, caution should be exercised when defining such

286 bacteria as commensals (Ghanbarpour and Oswald, 2010). Furthermore,

287 commensal E. coli can cause extra-intestinal disease when predisposing factors for

288 infection are present (Russo and Johnson, 2003). Therefore, although the majority of

289 the isolates investigated in this study may be phylogenetically classified as

290 commensal organisms, they may have the potential to be clinically significant.

291 Further refinement of this phylogenetic classification had recently been documented

292 by Clermont et al. (2013).

293

294 Adherence and invasion

295 Caco-2 cells, a homolog for enterocytes in the intestinal epithelium, were employed

296 to further assess the pathogenicity of isolates with different virulence gene profiles.

297 Bacterial adherence ranged from 6.31 to $7.73 \log _{10} \mathrm{cfu} \mathrm{mL}^{-1}$ and bacterial invasion

298 ranged from 1.35 to $5.36 \log _{10} \mathrm{cfu} \mathrm{mL}^{-1}$ for all 6 isolates (Figure 2). The non-ExPEC

299 iucD isolate (Eq23) was more adherent to Caco-2 cells $\left(0.85 \log _{10} \mathrm{cfu} \mathrm{mL} \mathrm{m}^{-1}, p \leq\right.$

$300 \quad 0.001)$ compared to the adherent control isolate as well as the other isolates

301 examined. However, this did not result in greater invasive ability. The only isolate to

302 be classed as invasive $\left(5.27 \log _{10} \mathrm{cfu}_{\mathrm{mL}}^{-1}, p \leq 0.05\right)$ was the ExPEC isolate (Eq67)

303 with the iucD-afa/draBC-papC virulence profile. Mellor et al. (2009) demonstrated 
304 that $E$. coli isolates considered pathogenic to humans do not display a greater ability

305 to attach to the Caco-2 cell line than those that are not. Perhaps cell lines modelling

306 other common ExPEC sites of infection, such as the human J-82 bladder homolog,

307 might reveal more about the potential these equine ExPEC have to cause infection.

309 Antimicrobial resistance profiles

310 All isolates demonstrated an MDR phenotype to critically important antimicrobial

311 agents for human medicine (WHO, 2017). Resistance was demonstrated to between

3124 and 13 of the antimicrobial agents tested with some 46 different resistance profiles

313 recognised (Supplemental Material Table S2). The majority of isolates (74 \%) were

314 resistant to 10 or more antimicrobial compounds. A summary of the frequency of

315 antimicrobial resistance is presented in Table 3.The most common MDR profile

316 among isolates (16\%) had resistance to 12 different compounds, including

317 ampicillin, trimethoprim, ciprofloxacin, streptomycin and tetracycline. Recently,

318 increasing numbers of MDR $E$. coli have been isolated from animal and human

319 sources (ECDC, 2017; Kennedy et al., 2017) and the acquisition of resistance genes

320 may convey a certain competitive advantage and ultimately lead to increased levels

321 of MDR E. coli in microbial populations (Webber et al., 2017).

\section{Occurrence of resistance determinants}

324 Antimicrobial agents frequently used in veterinary hospitals include broad-spectrumactivity drugs, such as $\beta$-lactams and fluoroquinolones. Thus, hospitalized animals may constitute an important reservoir of antimicrobial resistance (Karczmarczyk et

327 al., 2011a; WHO, 2017). Twenty-one percent of isolates possessed the commonly

328 reported tet( $\mathrm{A})$ gene, $61 \%$ possessed the tet $(\mathrm{G})$ gene and $15 \%$ of isolates carried 
329 both, accounting for 53 of the 81 tetracycline resistant isolates. Sixty-five percent of

330 the MDR equine E. coli isolates harboured one or more TEM, SHV and CTX-M-2

331 group $\beta$-lactamases (Table 3), as determined by PCR. The specific variants of these

$332 \beta$-lactamases were not identified. AmpC $\beta$-lactamases are cephalosporinases that

333 confer resistance to a wide variety of $\beta$-lactam drugs and give rise to serious

334 therapeutic challenges in veterinary and human medicine. $\beta$-Lactam resistance in $E$.

335 coli generally occurs as a result of deregulation of the putative ampC gene or the

336 acquisition of a mobile genetic element containing an ampC gene (Li et al., 2007).

337 The presence of plasmid-mediated ampC genes such as the blacmy variants were

338 not investigated here. In this study, the majority of isolates (79\%) were positive for

339 ampC and blatem (55\%). Isolates with the endogenous ampC gene and the narrow-

340 spectrum blatem-1 gene are common in animals (Li et al., 2007). Consequently, the

341 high rates of ampicillin-resistant blaтем-positive isolates among the equine collection,

342 was to be expected (Li et al., 2007).

343 Both TEM and SHV enzymes belong to the class A family of $\beta$-lactamases and are

344 widely disseminated among the Enterobacteriaceae from veterinary sources (Li et

345 al., 2007). In this study blatem was identified in over half the equine isolates however

346 blasHv was detected in only $4 \%$ of isolates. All were negative for blapse or blaoxA.

348 TEM enzymes often co-exist with CTX-M enzymes in bacteria of animal origin (Li et

349 al., 2007). CTX-M genes are currently regarded as the predominant extended-

350 spectrum $\beta$-lactam (ESBL) type of animal origin, while they have also been

351 associated with human isolates in Europe since the late 1990s (Bevan et al., 2017).

352 In Ireland, blacтX-M-mediated ESBL resistance is widespread (Burke et al., 2016,

353 Morris et al., 2016) however the number of blactX-M-2 group-positive isolates in this 
study was low $(n=5)$. To our knowledge, only one instance of blactX-M-2 has

355

356

357

358

359

360

361

362

363

364

365

366

367

368

369

370

371

372

373

374

375

376

377

378 previously been reported in animals in Ireland, as well as from bacteria of equine origin (Karczmarczyk et al., 2011a). These results are of interest considering the current epidemiology of these genes (Bevan et al., 2017).

Eighty-six percent of isolates were resistant to nalidixic acid, $79 \%$ were resistant to norfloxacin, $77 \%$ resistant to enrofloxacin and $73 \%$ resistant to ciprofloxacin. The high levels of resistance to quinolones and fluoroquinolones observed in this study are of medical concern, since ciprofloxacin is considered a very valuable antimicrobial agent and is the most effective drug in the treatment of Gram-negative bacterial infections, such as those caused by E. coli and Salmonella species (WHO, 2017). Ciprofloxacin resistance is generally conferred by mutations in target genes coding for DNA topoisomerases (gyrA, gyrB, parC, and parE) (Webber et al., 2017). Mutations in the DNA gyrase gyrA have been commonly reported in ciprofloxacinresistant E. coli and Salmonella isolates (Karczmarczyk et al., 2011b). All isolates in this study were found to have two amino acid substitutions in their GyrA subunit (D87Y and S83F).

\section{Distribution of integrons and gene cassettes}

Class 1 and class 2 integrons were detected among $85 \%$ of MDR E. coli isolated from diarrhoeagenic foals. Seventy-one percent of isolates were determined to possess the class 1 integrase gene (int/1), and just over half of these (54\%) also carried both the qacE $\Delta 1$ and sul1 genes. Class 1 integrons may be one of the mechanisms responsible for the rise in MDR E. coli in animal production environments (Kelly et al., 2009; Kennedy et al., 2017). Their contribution to 
379 resistance appears to be directed against antimicrobial compounds, including

380 streptomycin, trimethoprim and sulfonamides. The presence of class 1 integrons associated with resistance to trimethoprim, streptomycin, and sulfonamide, is in agreement with previous investigations (Kelly et al., 2009; Karczmarczyk et al.,

383 2011a; Kennedy et al., 2017).

384 PCR amplification with consensus primers targeting the regions flanking the gene cassettes yielded 6 different amplicons, ranging from 0.5 - to 2.5-kbp in size. Integrase I (int/1)-positive isolates possessed none (5\%), 1 (31\%), 2 (21\%), 3 (5 \%), $4(7 \%)$ or $5(2 \%)$ gene cassettes (Supplemental Material Table S2). A representative of each of these 6 gene cassettes was sequenced and annotated. A schematic representation of the gene cassettes is shown in Figure 3 . These include the aadA1 and aadA2 genes conferring aminoglycoside resistance, dfrA1 and $d f r A 2$ conferring trimethoprim resistance and sat1 conferring streptothricin resistance.

Fourteen percent of isolates carried class 2 integrons, as determined by amplification of the integrase gene (int/2). These isolates possessed none (2\%), $1(6 \%), 2(4 \%), 3$ (1\%) or $5(1 \%)$ gene cassettes (Supplemental Material Table S2). The most common cassettes carried by the int/2-positive isolates were the $0.5-\mathrm{kbp}(67 \%)$ and the 1.0 $\mathrm{kbp}$ cassettes (42\%). The variable gene cassette regions from within the integron structures identified were typical of cassettes present in class 1 and class 2 integron

398 structures in E. coli and are widely disseminated among the Enterobacteriaceae

399 (Kadlec et al. 2008). These results reveal the potential to transfer their MDR to other 400 pathogenic and non-pathogenic bacteria.

402 The development of MDR in any zoonotic bacterial species gives rise to the potential 403 for it to be transmitted from animals to humans and this could lead to major health 
404 issues such as the transfer of MDR to other human intestinal mircoflora as well as

405 other human pathogens that are traditionally susceptible to these agents (Kelly et al., 406 2009). MDR infections are associated with poorer clinical outcomes and higher cost

407 of treatment than other infections, and there are already reports of pan-resistant

408 strains in Gram-negative bacteria leading to treatment failure (Xiong et al., 2017).

409 Colonization of diarrhoeagenic foals with MDR E. coli is particularly challenging,

410 given the importance of these drugs. The ongoing usage of antimicrobial compounds

411 in the treatment of animals increases the selective pressure for emergence of MDR

412 organisms and dissemination of resistance (Webber et al., 2017).

413

414 Conclusion

415 The detection of potentially pathogenic MDR equine ExPEC in this study suggests a

416 need for heightened attention to be focused on companion/sport animals as possible

417 sources for human acquisition of disease-causing E. coli. Close monitoring of the

418 virulence and antimicrobial resistance of these bacterial populations, in order to

419 better understand their potential public health risk, is of great importance.

420

421 Acknowledgements

422 Funding for this research was provided by the Irish Equine Centre and through the

423 FIRM fund under the National Development Plan, administered by the Department of 424 Agriculture, Fisheries \& Food, Ireland. 
427 Anderson, M.A., Whitlock, J.E., Harwood, V.J., 2006. Diversity and distribution of

428 Escherichia coli genotypes and antibiotic resistance phenotypes in feces of humans,

429 cattle, and horses. Appl. Environ. Microbiol. 72, 6914-6922.

430 Baucheron, S., Imberechts, H., Chaslus-Dancla, E., Cloeckaert, A., 2002. The AcrB

431 multidrug transporter plays a major role in high-level fluoroquinolone resistance in

432 Salmonella enterica serovar Typhimurium phage type DT204. Microb. Drug

433 Resist. 8, 281-289.

434 Bevan, E.R., Jones, A.M., Hawkey, P.M., 2017. Global epidemiology of CTX-M $\beta-$

435 lactamases: temporal and geographical shifts in genotype. J. Antimicrob.

436 Chemother. 72, 2145-2155.

437 Burke, L., Humphreys, H. and Fitzgerald-Hughes, D., 2016. The Molecular

438 Epidemiology of Resistance in Cefotaximase-Producing Escherichia coli Clinical

439 Isolates from Dublin, Ireland. Microb. Drug Resist. 22, 552-558.

440 Byrne, L., Jenkins, C., Launders, N., Elson, R., Adak, G., 2015. The epidemiology, 441 microbiology and clinical impact of Shiga toxin-producing Escherichia coli in

442 England, 2009-2012. Epidemiol. Infect. 143, 3475-3487.

443 Ciesielczuk, H., Jenkins, C., Chattaway, M., Doumith, M., Hope, R., Woodford, N., 444 Wareham, D.W., 2016. Trends in ExPEC serogroups in the UK and their 445 significance. Clin. Microbiol. Infect. 35, 1661-1666.

446 Clermont, O., Bonacorsi, S., Bingen, E., 2000.Rapid and simple determination of the

447 Escherichia coli phylogenetic group. Appl. Environ. Microbiol. 66, 4555-4558.

448 Clermont, O., Christenson, J.K., Denamur, E., Gordon, D.M., 2013. The Clermont

449 Escherichia coli phylotyping method revisited: improvement of specificity and

450 detection of new phylogroups. Environ. Microbiol. Rep. 5, 58-65. 
451 Clinical and Laboratory Standards Institute (CLSI) 2013. Performance standards for antimicrobial disk and dilution susceptibility tests for bacteria isolated from animals. 4th ed. CLSI document VET01-A4. Clinical and Laboratory Standards Institute, 950 West Valley Road, Suite 2500, Wayne, PA 19087 USA.

Clinical and Laboratory Standards Institute (CLSI) 2015. Performance standards for antimicrobial disk and dilution susceptibility tests for bacteria isolated from animals. 3rd ed. CLSI supplement VET01S. Clinical and Laboratory Standards Institute, 950 West Valley Road, Suite 2500, Wayne, PA 19087 USA.

Croxen, M.A., Law, R.J., Scholz, R., Keeney, K.M., Wlodarska, M., Finlay, B.B., 2013. Recent advances in understanding enteric pathogenic Escherichia coli. Clin. Microbiol. Rev. 26, 822-880.

DebRoy, C., Roberts, E., Kundrat, J., Davis, M.A., Briggs, C.E., Fratamico, P.M., 2004. Detection of Escherichia coli serogroups $\mathrm{O} 26$ and $\mathrm{O} 113$ by PCR amplification of the wzx and wzy genes. Appl. Environ. Microbiol. 70, 1830-1832.

Duffy, G., O'Brien, S.B., Carney, E., Sheridan, J.J., McDowell, D.A., Blair, I.S., 2005. Characterisation of $E$. coli $\mathrm{O} 157$ isolates from bovine hide and beef trimming in Irish abattoirs by pulsed field gel electrophoresis. J. Microbiol. Methods 60, 375-382. European Centre for Disease Prevention and Control.Surveillance of antimicrobial resistance in Europe 2016.Annual Report of the European Antimicrobial Resistance

470 Surveillance Network (EARS-Net). Stockholm: ECDC; 2017.

471 Ewers, C., Bethe, A., Stamm, I., Grobbel, M., Kopp, P.A., Guerra, B., Stubbe, M., 472 Doi, Y., Zong, Z., Kola, A., Schaufler, K., 2014. CTX-M-15-D-ST648 Escherichia coli 473 from companion animals and horses: another pandemic clone combining 474 multiresistance and extraintestinal virulence?. J. Antimicrob. Chemother. 69, 1224$475 \quad 1230$. 
476 Gannon, V.P., King, R.K., Kim, J.Y., Thomas, E.J., 1992. Rapid and sensitive method for detection of Shiga-like toxin-producing Escherichia coli in ground beef using the polymerase chain reaction. Appl. Environ. Microbiol. 58, 3809-3815. Ghanbarpour, R., Oswald, E., 2010. Phylogenetic distribution of virulence genes in

480 Escherichia coli isolated from bovine mastitis in Iran. Res. Vet. Sci. 88, 6-10.

481 Holland, R.E., Schmidt, A., Sriranganathan, N., Grimes, S.D., Wilson, R.A., Brown, 482 C.M., Walker, R.D., 1996. Characterization of Escherichia coli isolated from foals. Vet. Microbiol. 48, 243-255. Johnson, J.R., Stell, A.L., 2000. Extended virulence genotypes of Escherichia coli strains from patients with urosepsis in relation to phylogeny and host compromise. J. 486 Infect. Dis. 181, 261-272.

487 Kadlec, K., Schwarz, S., 2008. Analysis and distribution of class 1 and class 2 integrons and associated gene cassettes among Escherichia coli isolates from swine, horses, cats and dogs collected in the BfT-GermVet monitoring study. J.

490 Antimicrob. Chemother. 62, 469-473.

491 Karczmarczyk, M., Abbott, Y., Walsh, C., Leonard, N. and Fanning, S., 2011 a.

492 Characterization of multidrug-resistant Escherichia coli isolates from animals 493 presenting at a university veterinary hospital. Appl. Environ. Microbiol. 77, 71044947112.

495 Karczmarczyk, M., Martins, M., Quinn, T., Leonard, N. and Fanning, S., 496 2011b.Mechanisms of fluoroquinolone resistance in Escherichia coli isolates from 497 food-producing animals. Appl. Environ. Microbiol. 77, 7113-7120.

498 Kelly, B.G., Vespermann, A., Bolton, D.J., 2009. Horizontal gene transfer of virulence 499 determinants in selected bacterial foodborne pathogens. Food Chem. Toxicol. 47, $500 \quad 969-977$. 
501 Kennedy, C.A., Fanning, S., Karczmarczyk, M., Byrne, B., Monaghan, A., Bolton, D.,

502 Sweeney, T., 2017. Characterizing the multidrug resistance of non-O157 Shiga

503 Toxin-Producing Escherichia coli isolates from cattle farms and abattoirs. Microb.

504 Drug Resist. 23, 781-790.

505 Krause, G., Zimmermann, S., Beutin, L., 2005. Investigation of domestic animals and

506 pets as a reservoir for intimin-(eae) gene positive Escherichia coli types. Vet.

507 Microbiol. 106, 87-95.

508 Kyle, J.L., Parker, C.T., Goudeau, D., Brandl, M.T., 2010.Transcriptome analysis of

509 Escherichia coli 0157:H7 exposed to lysates of lettuce leaves. Appl. Environ.

510 Microbiol. 76, 1375-87.

511 Lenahan, M., O’Brien, S., Kinsella, K., Sweeney, T., Sheridan, J.J., 2007.

512 Prevalence and molecular characterization of Escherichia coli O157: H7 on Irish

513 lamb carcasses, fleece and in faeces samples. J. Appl. Microbiol. 103, 2401-2409.

514 Lenahan, M., O’Brien, S.B., Byrne, C., Ryan, M., Kennedy, C.A., McNamara, E.B.,

515 Fanning, S., Sheridan, J.J., Sweeney, T., 2009. Molecular characterization of Irish E.

516 coli O157: $\mathrm{H} 7$ isolates of human, bovine, ovine and porcine origin. J. Appl. Microbiol.

517 107, 1340-1349.

518 Li, X.Z., Mehrotra, M., Ghimire, S., Adewoye, L., 2007. $\beta$-Lactam resistance and $\beta$ -

519 lactamases in bacteria of animal origin. Vet. Microbiol. 121, 197-214.

520 Mellor, G.E., Goulter, R.M., Chia, T.R., Dykes, G.A., 2009. Comparative analysis of

521 attachment of Shiga-toxigenic Escherichia coli and Salmonella strains to cultured

522 HT-29 and Caco-2 cell lines. Appl. Environ. Microbiol. 75, 1796-1799.

523 Mora, A., Herrrera, A., López, C., Dahbi, G., Mamani, R., Pita, J.M., Alonso, M.P.,

524 Llovo, J., Bernárdez, M.I., Blanco, J.E., Blanco, M., 2011. Characteristics of the 
Shiga-toxin-producing enteroaggregative Escherichia coli O104: H4 German

outbreak strain and of STEC strains isolated in Spain. Int. Microbiol. 14, 121-141.

527

Morris, D., O'connor, M., Izdebski, R., Corcoran, M., Ludden, C.E., McGrath, E.,

528 Buckley, V., Cryan, B., Gniadkowski, M., Cormican, M., 2016. Dissemination of

529 clonally related multidrug-resistant Klebsiella pneumoniae in Ireland. Epidemiol.

$530 \quad$ Infect. 144, 443-448.

531 Murray, R., Tataryn, J., Pintar, K., Thomas, M.K., 2017. Estimates of the burden of

532 illness for eight enteric pathogens associated with animal contact in Canada.

533 Epidemiol. Infect. 145, 3413-3423.

534 Naves, P., del Prado, G., Huelves, L., Gracia, M., Ruiz, V., Blanco, J., Dahbi, G.,

535 Blanco, M., del Carmen Ponte, M., Soriano, F., 2008. Correlation between virulence

536 factors and in vitro biofilm formation by Escherichia coli strains. Microb Pathog 45,

537 86-91.

538 Nyholm, O., Heinikainen, S., Pelkonen, S., Hallanvuo, S., Haukka, K., Siitonen, A.,

539 2015. Hybrids of Shigatoxigenic and enterotoxigenic Escherichia coli (STEC/ETEC)

540 among human and animal isolates in Finland. Zoonoses Public Health 62, 518-524.

541 Paton, A.W., Paton, J.C., 1998. Detection and characterization of Shiga toxigenic

542 Escherichia coli by using multiplex PCR assays for stx1, stx2, eaeA,

543 enterohemorrhagic E. coli hlyA, rfb 0111, and rfb O157. J. Clin. Microbiol. 36, 598-

544602.

545 Russo, T.A., Johnson, J.R., 2003. Medical and economic impact of extraintestinal

546 infections due to Escherichia coli: focus on an increasingly important endemic

547 problem. Microb. Infect. 5, 449-456. 
548 Sandvang, D., Aarestrup, F.M., Jensen, L.B., 1998. Characterisation of integrons and antibiotic resistance genes in Danish multiresistant Salmonella entericaTyphimurium DT104. FEMS Microbiol. Lett. 160, 37-41.

551 Sheridan, À., Lenahan, M., Duffy, G., Fanning, S., Burgess, C., 2012. The potential

552 for biocide tolerance in Escherichia coli and its impact on the response to food

553 processing stresses.Food Control 26, 98-106.

554 Siqueira, A.K., Ribeiro, M.G., Leite, D.D.S., Tiba, M.R., de Moura, C., Lopes, M.D., Prestes, N.C., Salerno, T., da Silva, A.V., 2009. Virulence factors in Escherichia coli strains isolated from urinary tract infection and pyometra cases and from feces of

557 healthy dogs. Res. Vet. Sci. 86, 206-210.

558 Simpson, K.W., Dogan, B., Rishniw, M., Goldstein, R.E., Klaessig, S., McDonough, 559 P.L., German, A.J., Yates, R.M., Russell, D.G., Johnson, S.E., Berg, D.E., 2006. 560 Adherent and invasive Escherichia coli is associated with granulomatous colitis in 561 boxer dogs. Infect. Immun. 74, 4778-4792.

562 Vally, H., Hall, G., Dyda, A., Raupach, J., Knope, K., Combs, B., Desmarchelier, P., 563 2012. Epidemiology of Shiga toxin producing Escherichia coli in Australia, 2000564 2010.BMC Public Health 12, 63-74.

565 Van Duijkeren, E., Van Asten, A.J.A.M., Gaastra, W., 2000. Characterization of 566 Escherichia coli isolated from adult horses with and without enteritis. Vet. Quart. 22, 567 162-166.

568 Wiles, T.J., Kulesus, R.R., Mulvey, M.A., 2008. Origins and virulence mechanisms of uropathogenic Escherichia coli. Exp. Mol. Pathol. 85, 11-19.

570 Winokur, P.L., Brueggemann, A., DeSalvo, D.L., Hoffmann, L., Apley, M.D.,

571 Uhlenhopp, E.K., Pfaller, M.A., Doern, G.V., 2000. Animal and human multidrug572 resistant, cephalosporin-resistant Salmonella isolates expressing a plasmid- 
573 mediated CMY-2 AmpC $\beta$-lactamase. Antimicrob. Agents Chemother. 44, 2777-

5742783.

575 Webber, M.A., Buckner, M.M., Redgrave, L.S., Ifill, G., Mitchenall, L.A., Webb, C.,

576 Iddles, R., Maxwell, A., Piddock, L.J., 2017. Quinolone-resistant gyrase mutants

577 demonstrate decreased susceptibility to triclosan. J. Antimicrob. Chemother. 72,

$578 \quad 2755-2763$.

579 Werber, D., Beutin, L., Pichner, R., Stark, K., Fruth, A., 2008. Shiga toxin-producing

580 Escherichia coli serogroups in food and patients, Germany. Emerg. Infect. Diseases

$581 \quad 14,1803-1806$.

582 World Health Organization, 2017. Critically important antimicrobials for human

583 medicine: ranking of antimicrobial agents for risk management of antimicrobial

584 resistance due to non-human use. ISBN 978-92-4-151222-0

585 Xia, X., Meng, J., Zhao, S., Bodeis-Jones, S., Gaines, S.A., Ayers, S.L., McDermott,

586 P.F., 2011. Identification and antimicrobial resistance of extraintestinal pathogenic

587 Escherichia coli from retail meats. J. Food Prot. 74, 38-44.

588 Xiong, J., Déraspe, M., Iqbal, N., Krajden, S., Chapman, W., Dewar, K., Roy, P.H.,

589 2017. Complete genome of a panresistant Pseudomonas aeruginosa strain, isolated

590 from a patient with respiratory failure in a canadian community hospital. Genome

591 Announc. 5, e00458-17.

592 Xu, L., Ensor, V., Gossain, S., Nye, K., Hawkey, P., 2005. Rapid and simple

593 detection of blactx-m genes by multiplex PCR assay. J. Med. Microbiol. 54, 1183-

5941187.

595 Zhou, X.Y., Bordon, F., Sirot, D., Kitzis, M.D., Gutmann, L., 1994.Emergence of

596 clinical isolates of Escherichia coli producing TEM-1 derivatives or an OXA-1 beta- 
597 lactamase conferring resistance to beta-lactamase inhibitors. Antimicrob. Agents

598 Chemother. 38, 1085-1089.

599

600 Tables

601 Table 1: PCR primer characteristics

602 Table 2: Typable equine E. coli strains as determined by Public Health England

603 Table 3: The percentage of antibiotic resistance, resistance markers and virulence

604 genes among equine E. coli isolates.

605

606 Figure captions

607 Figure 1: Dendrogram showing genotypic similarities between the equine $E$. coli

608 isolates $(n=83)$ based on pulsotypes.

609 Figure 2: Adherence (A) and invasion (B) of Caco-2 cells by equine $E$. coli isolates

610 positive or negative for virulence genes.

611 Figure 3: Schematic representation of the organization of sequenced gene cassettes 612 of class 1 integrons.

613 


\section{Figure legends}

\section{2}

3 Figure 2 legend: Adhesion (A) and invasion (B) of equine E. coli to human Caco-2

4 cells. Values indicate means of three separate experiments \pm S.E. The results of

5 statistical analysis are indicated by the letters $a, b$ and $c$. Strains with different letters

6 are significantly different from each other $(p<0.05)$.

7 Figure 3 legend: aad - aminoglycoside adenyltransferase; att/1 - Integron associated

8 recombination site; $d f r$ - dihydrofolate reductase; sat1 - streptothricin acetyl

9 transferase; $59 \mathrm{bp}$ - 59 base pair element recombination site; hp - hypothetical

10 protein; CS - conserved segment. Arrowheads represent the direction of the 11 transcription. 


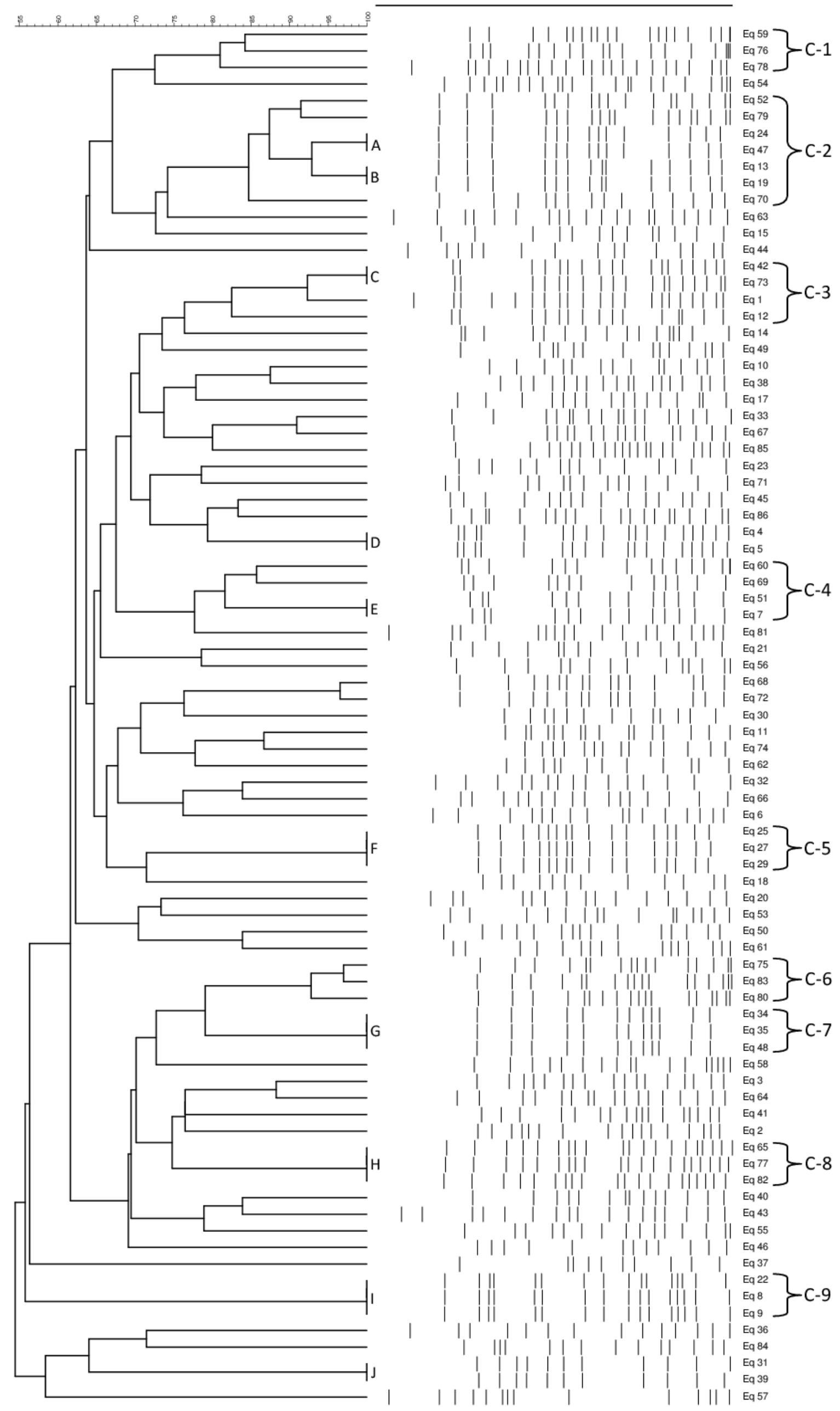


1 Table 1:PCR primer characteristics

\begin{tabular}{|c|c|c|c|c|}
\hline & & Sense $^{a}$ & Primer sequence (5'-to-3') & Reference \\
\hline \multirow[t]{3}{*}{ Serogroup } & $r f b 0157$ & $\begin{array}{l}\mathrm{F} \\
\mathrm{R}\end{array}$ & $\begin{array}{l}\text { CGG ACA TCC ATG TGA TAT GG } \\
\text { TTG CCT ATG TAC AGC TAA TCC }\end{array}$ & Paton and Paton, 1998 \\
\hline & $r f b \circ 111$ & $\begin{array}{l}\mathrm{F} \\
\mathrm{R}\end{array}$ & $\begin{array}{l}\text { TAG AGA AAT TAT CAA GTT AGT TCC } \\
\text { ATA GTT ATG AAC ATC TTG TTT AGC }\end{array}$ & Paton and Paton, 1998 \\
\hline & $r f b 026$ & $\begin{array}{l}\mathrm{F} \\
\mathrm{R}\end{array}$ & $\begin{array}{l}\text { GCG CTG CAA TTG CTT ATG TA } \\
\text { TTT CCC CGC AAT TTA TTC AG }\end{array}$ & Debroy et al., 2004 \\
\hline $\begin{array}{l}\text { Phylogenetic } \\
\text { Group }\end{array}$ & chuA & $\begin{array}{l}\mathrm{F} \\
\mathrm{R}\end{array}$ & $\begin{array}{l}\text { GACGAACCAACGGTCAGGAT } \\
\text { TGCCGCCAGTACCAAAGACA }\end{array}$ & Clermont et al., 2000 \\
\hline \multirow{2}{*}{ Group } & $y j a A$ & $\begin{array}{l}\mathrm{F} \\
\mathrm{R}\end{array}$ & $\begin{array}{l}\text { TGAAGTGTCAGGAGACGCTG } \\
\text { ATGGAGAATGCGTTCCTCAAC }\end{array}$ & Clermont et al., 2000 \\
\hline & TSPE4C2 & $\begin{array}{l}\mathrm{F} \\
\mathrm{R}\end{array}$ & $\begin{array}{l}\text { GAGTAATGTCGGGGCATTCA } \\
\text { CGCGCCAACAAAGTATTGCG }\end{array}$ & Clermont et al., 2000 \\
\hline \multirow[t]{11}{*}{$\begin{array}{l}\text { Virulence } \\
\text { Gene }\end{array}$} & stx1 & $\begin{array}{l}\mathrm{F} \\
\mathrm{R}\end{array}$ & $\begin{array}{l}\text { ACA CTG GAT GAT CTC AGT GG } \\
\text { CTG AAT CCC CCT CCA TTA TG }\end{array}$ & Gannon et al., 1992 \\
\hline & stx2 & $\begin{array}{l}\mathrm{F} \\
\mathrm{R}\end{array}$ & $\begin{array}{l}\text { CCA TGA CAG ACG GAC AGC AGT T } \\
\text { CCT GTC AAG CTG AGC ACT TTG }\end{array}$ & Gannon et al., 1992 \\
\hline & eaeA & $\begin{array}{l}\mathrm{F} \\
\mathrm{R}\end{array}$ & $\begin{array}{l}\text { GAC CCG GCA CAA GCA TAA GC } \\
\text { CCA CCT GCA GCA ACA AGA GG }\end{array}$ & Lenahan et al., 2007 \\
\hline & hlyA & $\begin{array}{l}\mathrm{F} \\
\mathrm{R}\end{array}$ & $\begin{array}{l}\text { GCA TCA TCA AGC GTA CGT TCC } \\
\text { AAT GAG CCA AGC TGG TTA AGC T }\end{array}$ & Lenahan et al., 2007 \\
\hline & flich7 & $\begin{array}{l}\mathrm{F} \\
\mathrm{R}\end{array}$ & $\begin{array}{l}\text { GCGCTGTCGAGTTCTATCGAGC } \\
\text { CAACGGTGACTTTATCGCCATTCC }\end{array}$ & Lenahan et al., 2007 \\
\hline & cnf1 & $\begin{array}{l}\mathrm{F} \\
\mathrm{R}\end{array}$ & $\begin{array}{l}\text { GAA CTT ATT AAG GAT AGT } \\
\text { CAT TAT TTA TAA CGC TG }\end{array}$ & Siqueira et al., 2009 \\
\hline & $\begin{array}{l}\text { iucD (aerobactin } \\
\text { operon) }\end{array}$ & $\begin{array}{l}\mathrm{F} \\
\mathrm{R}\end{array}$ & $\begin{array}{l}\text { TAC CGG ATT GTC ATA TGC AGA CCG T } \\
\text { AAT ATC TTC CTC CAG TCC GGA GAA G }\end{array}$ & Siqueira et al., 2009 \\
\hline & papC & $\begin{array}{l}\mathrm{F} \\
\mathrm{R}\end{array}$ & $\begin{array}{l}\text { GAC GGC TGT ACT GCA GGG TGT GGC G } \\
\text { ATA TCC TTT CTG CAG GGA TGC AAT A }\end{array}$ & Siqueira et al., 2009 \\
\hline & $s f a / f o c D E$ & $\begin{array}{l}\mathrm{F} \\
\mathrm{R}\end{array}$ & $\begin{array}{l}\text { CTC CGG AGA ACT GGG TGC ATC TTA C } \\
\text { CGG AGG AGT AAT TAC AAA CCT GGC A }\end{array}$ & Siqueira et al., 2009 \\
\hline & $a f a / d r a B C$ & $\begin{array}{l}\mathrm{F} \\
\mathrm{R}\end{array}$ & $\begin{array}{l}\text { GCT GGG CAG CAA ACT GAT AAC TCT C } \\
\text { CAT CAA GCT GTT TGT TCG TCC GCC G }\end{array}$ & Siqueira et al., 2009 \\
\hline & $\operatorname{neu} C(K 1)$ & $\begin{array}{l}\mathrm{F} \\
\mathrm{R}\end{array}$ & $\begin{array}{l}\text { AGG TGA AAA GCC TGG TAG TGT G } \\
\text { GGT GGT ACA TCC CGG GAT GTC }\end{array}$ & Johnson \& Stell, 2000 \\
\hline \multirow[t]{9}{*}{$A^{R}$ Gene } & blateм & $\begin{array}{l}\mathrm{F} \\
\mathrm{R}\end{array}$ & $\begin{array}{l}\text { GTA TGG ATC CTC AAC ATT TCC GTG TCG } \\
\text { ACC AAA GCT TAA TCA GTG AGG CA }\end{array}$ & Zhou et al., 1994 \\
\hline & blapse & $\begin{array}{l}\mathrm{F} \\
\mathrm{R}\end{array}$ & $\begin{array}{l}\text { CGC TTC CCG TTA ACA ACT AC } \\
\text { CTG GTT CAT TTC AGA TAG CG }\end{array}$ & Winokur et al., 2000 \\
\hline & blashv & $\begin{array}{l}\mathrm{F} \\
\mathrm{R}\end{array}$ & $\begin{array}{l}\text { TCA GCG AAA AAC ACC TTG } \\
\text { TCC CGC AGA TAA ATC ACC A }\end{array}$ & Kennedy et al., 2017 \\
\hline & blaoxa & $\begin{array}{l}\mathrm{F} \\
\mathrm{R}\end{array}$ & $\begin{array}{l}\text { TAT CTA CAG CAG CGC CAG TG } \\
\text { CGC ATC AAA TGC CAT AAG TG }\end{array}$ & Kennedy et al., 2017 \\
\hline & $a m p C$ & $\begin{array}{l}\mathrm{F} \\
\mathrm{R}\end{array}$ & $\begin{array}{l}\text { CCC CGC TTA TAG AGC AAC AA } \\
\text { TCA ATG GTC GAC TTC ACA CC }\end{array}$ & Kennedy et al., 2017 \\
\hline & $\operatorname{tet}(\mathrm{A})$ & $\begin{array}{l}\mathrm{F} \\
\mathrm{R}\end{array}$ & $\begin{array}{l}\text { GCT ACA TCC TGC TTG CCT TC } \\
\text { CAT AGA TCG CCG TGA AGA GG }\end{array}$ & Kennedy et al., 2017 \\
\hline & $\operatorname{tet}(\mathrm{G})$ & $\begin{array}{l}\mathrm{F} \\
\mathrm{R}\end{array}$ & $\begin{array}{l}\text { GCT CGG TGG TAT CTC TGC TC } \\
\text { AGC AAC AGA ATC GGG AAC AC }\end{array}$ & Kennedy et al., 2017 \\
\hline & blactх-м-2 group & $\begin{array}{l}\mathrm{F} \\
\mathrm{R}\end{array}$ & $\begin{array}{l}\text { TGA TAC CAC CAC GCC GCT C } \\
\text { TAT TGC ATC AGA AAC CGT GGG }\end{array}$ & Xu et al., 2005 \\
\hline & gyrA & $\begin{array}{l}\mathrm{F} \\
\mathrm{R}\end{array}$ & $\begin{array}{l}\text { TGT CCG AGA TGG CCT GAA GC } \\
\text { CGT TGA TGA CTT CCG TCA G }\end{array}$ & Baucheron et al., 2002 \\
\hline \multirow[t]{5}{*}{$\begin{array}{l}\text { Integron } \\
\text { Components }\end{array}$} & gene cassette & $\begin{array}{l}\mathrm{F} \\
\mathrm{R}\end{array}$ & $\begin{array}{l}\text { GGC ATC CAA GCA GCA AGC } \\
\text { AAG CAG ACT TGA CCT GAT }\end{array}$ & Sandvang et al., 1998 \\
\hline & int/1 & $\begin{array}{l}\mathrm{F} \\
\mathrm{R}\end{array}$ & $\begin{array}{l}\text { GTG GAT GGC GGC CTG AAG CC } \\
\text { ATT GCC CAG TCG GCA GCG }\end{array}$ & Sandvang et al., 1998 \\
\hline & int12 & $\begin{array}{l}\mathrm{F} \\
\mathrm{R}\end{array}$ & $\begin{array}{l}\text { CAC GGA TAT GCG ACA AAA AGG T } \\
\text { GTA GCA AAC GAG TGA CGA AAT G }\end{array}$ & Kennedy et al., 2017 \\
\hline & sul1 & $\begin{array}{l}\mathrm{F} \\
\mathrm{R}\end{array}$ & $\begin{array}{l}\text { CTT CGA TGA GAG CCG GCG GC } \\
\text { GCA AGG CGG AAA CCC GCG CC }\end{array}$ & Sandvang et al., 1998 \\
\hline & qacEA1 & $\begin{array}{l}\mathrm{F} \\
\mathrm{R}\end{array}$ & $\begin{array}{l}\text { ATC GCA ATA GTT GGC GAA GT } \\
\text { CAA GCT TTT GCC CAT GAA GC }\end{array}$ & Sandvang et al., 1998 \\
\hline
\end{tabular}


1 Table 2: Typeable E. coli strains as determined by conventional serotyping of 25 2 representative $E$. coli isolates and in-house PCR recovered from diarrhoeagenic 3 foals by the Irish Equine Centre

\begin{tabular}{lll}
\hline & Isolate Code & Serotype \\
\hline Conventional Serotyping & Eq4 & E. coli O1 \\
& Eq48 & E. coli O1 \\
& Eq74 & E. coli O101 \\
& Eq50 & E. coli O153 \\
& Eq77 & E. coli O153 \\
& Eq44 & E. coli O19a \\
& Eq54 & E. coli O33 \\
& Eq45 & E. coli O40 \\
& Eq75 & E. coli O91 \\
In house PCR serotyping & Eq64 & E. coli O26 \\
\hline
\end{tabular}

4 Serotyping results for the remaining 16 isolates were not available, as the isolates were

5 'unidentifiable' using traditional serotyping techniques. 
1 Table 3: Antibiotic resistance, associated resistance markers, and virulence genes

2 among equine $E$. coli isolates

\begin{tabular}{|c|c|}
\hline Antimicrobial Agents & $\%$ Resistance \\
\hline Ampicillin* & 93 \\
\hline Amikacin* & 6 \\
\hline Amoxillin/clavulanic acid* & 30 \\
\hline Gentamicin* & 68 \\
\hline Ciprofloxacin* & 73 \\
\hline Enrofloxacin* & 77 \\
\hline Kanamycin* & 70 \\
\hline Cefalothin & 67 \\
\hline Naladixic Acid ${ }^{*}$ & 86 \\
\hline Norfloxacin* & 79 \\
\hline Streptomycin $^{*}$ & 98 \\
\hline Sulfonamide & 98 \\
\hline Tetracycline & 96 \\
\hline Trimethoprim & 98 \\
\hline Integron Components & $\%$ Present \\
\hline intl1 & 71 \\
\hline int12 & 14 \\
\hline qacE $\Delta 1$ & 71 \\
\hline sul1 & 57 \\
\hline Gene Cassettes (kb) & $\%$ Present \\
\hline 0.5 & 64 \\
\hline 1.0 & 40 \\
\hline 1.5 & 35 \\
\hline 1.7 & 10 \\
\hline 2.0 & 4 \\
\hline 2.5 & 6 \\
\hline $\begin{array}{l}\text { Antibiotic Resistance } \\
\text { Determinants }\end{array}$ & $\%$ Present \\
\hline$a m p C$ & 80 \\
\hline blasHV & 4 \\
\hline $\operatorname{tet}(\mathrm{A})$ & 21 \\
\hline $\operatorname{tet}(\mathrm{G})$ & 61 \\
\hline$b / a_{\mathrm{TEM}}$ & 55 \\
\hline blactX-M-2 group & 6 \\
\hline Virulence Genes & $\%$ Present \\
\hline$i u c D$ & 57 \\
\hline$a f a / d r a B C$ & 31 \\
\hline papC & 36 \\
\hline sfa/focDE & 2 \\
\hline
\end{tabular}


